\title{
Blended learning technology in fostering linguistic skills: problems and solutions at higher education
}

\section{Solijon AZIZOV ${ }^{1}$ Gulandom BAKIEVA $^{2}$}

Uzbekistan State World Languages University

\begin{tabular}{l} 
ARTICLE INFO \\
\hline Article history: \\
Received September 2020 \\
Received in revised form \\
15 September 2020 \\
Accepted 15 October 2020 \\
Available online \\
30 October 2020 \\
\hline Keywords: \\
Blended learning technology \\
Higher education \\
Innovation \\
Online platform \\
Offline platform
\end{tabular}

\begin{abstract}
The article deals with the basic problems of teaching foreign languages at higher education institutions, in particular teaching English by implementing the blended learning approach into practice. The solutions to those problems have been considered based on the results of the research on uniting both the online and offline platforms of improving students' basic linguistic skills in a systematic way as the innovative means of consolidating the quality and content factors of higher education remarkably.

Furthermore, the ways of assessing and providing students with feedback about their progress in fostering their linguistic skills in the target language have been applied into the practical part of the investigation, and the results have been characterized according to the choices of the research participants in the questionnaires2181-1415/C 2020 in Science LLC.
\end{abstract}

This is an open access article under the Attribution 4.0 International (CC BY 4.0) license (https://creativecommons.org/licenses/by/4.0/deed.ru)

\section{Blended таълим технологияси тил кўникмаларини оширишда: олий таълимда муаммолар ва ечимлар}

\section{АННОТАЦИЯ}

\section{Калит сўзлар:}

Blended таълим

технологияси

Олий таълим

Инновация

Онлайн платформа

Офлайн платформа
Мақолада олий таълим муассасаларида чет тилларни ўқитишнинг асосий муаммолари инглиз тилини ўқитиш жараёнига blended таълим технологиясини жорий этган холдаги жараён мисолида тақдим этилди ва натижада анъанавий таълим машғулотларида мавжуд бўлган муаммоларнинг ечимлари олий таълимнинг сифат ва мазмун факторларини сезиларли равишда мустахкамлашнинг инновацион воситалари сифатида

\footnotetext{
${ }^{1} \mathrm{PhD}$ student, Uzbekistan State World Languages University, Tashkent, Uzbekistan

Email: solijonazizov1@gmail.com

${ }^{2}$ Doctor of philological sciences, Professor, Uzbekistan State World Languages University, Tashkent, Uzbekistan

Email: uzswlu_ilmiy@mail.ru
} 
талабаларнинг асосий лингвистик кўникмаларини тизимли оширишнинг онлайн ва офлайн платформаларини ўзаро бирлаштириш мавзусида олиб борилган тадқиқот натижаларига асосланган холда кўриб чиқилган.

Шунингдек, талабаларни бахолаш ва уларнинг асосий ўрганилаётган чет тилидаги лингвистик кўникмаларини оширишдаги муваффаққиятлари юзасидан фикрмулохазалар билан таъминлашнинг инновацион усуллари тадқиқотнинг амалий жараён қисмига тадбиқ этилди ва мақолада натижалар тадқиқот иштирокчиларининг сўровномалардаги танловларига кўра батафсил тавсифланди.

\section{Технология обучения blended в применении языковых навыков: проблемы и решения в высшем образовании}

\author{
Ключевые слова: \\ Технология обучения \\ blended \\ Высшее образование \\ Инновация \\ Онлайн-платформа \\ Оффлайн-платформа
}

\begin{abstract}
АННОТАЦИЯ
В данной статье раскрываются основные проблемы преподавания иностранных языков в высших образовательных учреждениях. В частности, рассмотрено решение проблем, возникающих во время традиционных учебных занятий и представлены примеры реализации подхода blended learning в обучении английскому языку. Как свидетельствуют результаты проведенного исследования, при совмещении инновационных средств онлайн- и оффлайн-платформ реализация данного подхода способствует систематическому развитию основных языковых навыков у студентов, что приводит к значительному повышению качества содержания высшего образования.

Кроме того, в практической части исследования применены методы оценивания и предоставления студентам обратной связи, свидетельствующие об их успехах в развитии лингвистических навыков на занятиях основного изучаемого иностранного языка, а также результаты подробно охарактеризованы в соответствии с данными анкетирования участников.
\end{abstract}

\section{INTRODUCTION}

Higher education is getting updated via a number of innovations to optimize the process of providing both teachers and students with high quality education and sources in practice. Therefore, it is more advisory and beneficial to apply modern technological means into teaching particular fields of science, thereby making a great deal of progress. Accordingly, we can state that the blended learning approach has played an important role in uniting the traditional place-based classroom activities and information and communications technology significantly well since the 1960s [15]. In addition, the blended learning technologies can be effectively implemented into the process of teaching foreign languages, for example, English and fostering the basic five linguistic skills with the 
help of modern innovative means according to the objectives of our research on this matter. As Shavkat Mirziyoyev states: "Today, every teacher, educator, university lecturer must have deep knowledge and a broad worldview, actively master the latest achievements of science, education and introduce them into the educational process, in a word, must be an advanced representative of our time and society [1]. Accordingly, it is important to analyze the theoretical and practical basis of uniting both offline and online platforms of teaching foreign languages at higher education in order to consolidate the content and quality factors of the continuous education remarkably well.

Given that implementing the blended learning approach into practice is the ongoing process, our research aims to analyze the ways of forming online and offline platforms of fostering students' linguistic skills in the target language (e.g. English) taking the requirements and measures of higher education. Therefore, the studies on this matter show that while fostering the basic linguistic skills of students at higher education there are certain principles and features of the approach to be strictly paid attention. For instance, the term 'blended learning' was vague because of which encompassed different pedagogical methods and technologies [15], thereby meaning this concept until 2006 when the first publication 'Handbook of Blended learning' by Bonk and Graham in which Graham managed to make the term more concrete by defining 'blended learning systems' as the combination of the instructions of face-to-face and computer mediated in science [5]. Following that another researcher suggested that the system of following the blended learning approach could present a number of possibilities in practice because of the virtual technological means by requiring the co-presence of teacher and students [6] which we also consider to be the most crucial part of the research to consolidate the continuous education significantly. According to the objectives of our research, we had decided to choose the platforms of social networking services (SNS) and messengers as the online platforms of our research in fostering students' linguistic skills and the traditional place-based lesson activities at university as the offline platforms. Hence, by doing this investigation the theoretical and practical basis of this matter could be formed effectively. Moreover, one advantage of the blended learning approach is that one instructor can teach so many students at the same time on the virtual platforms of the process [4]. According to the functions and possibilities of the blended learning systems, there are certain models in practice, such as face-to-face driver (the teacher's driving the instructions via digital tools) [10], rotation (students' cycling through a schedule of free online and offline studies) [8], flex (delivering most of the curriculum via a digital platform with teachers' face-to-face support and consultation) [13], self-blend (students' deciding to augment their face-to-face studies with online ones themselves) [10], online driver (having the whole study curriculum online with face-to-face instructions if necessary) [11]. It is worth mentioning that although the above-mentioned models can be utilized together, they are not distinctly exclusive for the most part in practice according to the research literature [12].

However, there exist arguable discussions on this matter between the researchers who disapprove of the implementation of the blended learning approach into practice, but the studies on approving of the efficiency of the approach have proved the more productivity of following this approach than purely online or offline studies [14], resulting in high levels of student achievements via this approach [9], facilitating a simultaneous independent and collaborative learning experience at higher education [7], effects of using ICT on improving students' attitudes towards learning subjects [2], and enabling students to be able to evaluate their understanding course materials via the use of "computer-based 
qualitative and quantitative assessment modules" [3] which is considered to be one of the most important factors of increasing the actuality of our research in practice. So, based on the above-mentioned analyses, we had also done the investigations and experiments on forming the theoretical and practical basis of implementing the blended learning approach into fostering students' basic linguistic skills in the example of the English language on the modern innovative virtual platforms of SNS and messengers and offline platforms, traditional face-to-face lessons with the help of ICT.

\section{MATERIALS AND METHODS.}

When practical results of a certain investigation are obtained positively, this or that research means to be implemented into practice fully if appropriate methods and materials are utilized during this or that research. Therefore, in this part of the article, the materials and methods of the research will be presented in detail. Before starting to present the practical results of the research in the next part 'Results and its discussion', it is worth illustrating the subjects of the research. So, before implementing the research methods into practice, we had selected two groups of the second-year students at evening education of Uzbekistan State World Languages University where we conducted our practice lessons. The groups were 204 and 208 of the Philology faculty at evening education where 8 students were in group 204 and 10 students were in group 208, and the number of the students who attended our research in total was 18. As for the ages of the participants (students) during the academic year 2019/2020 were between 21 and 27 years old. During the practice period, we had lessons of Speaking, Listening, Reading, Writing, and Practical Grammar skills. As for the language levels of the students, there were students (language learners) of different levels (B1 and B2). Moreover, none of the student was a native speaker and lived with a native speaker. Besides, we had asked two teachers of the department as well to observe our research and participate our questionnaires in order to get their reflections on our investigations. After having figured out the abovementioned information about the subjects of our investigation, we divided them into two, namely the group of students who participated the whole process and the group of teachers who observed the method and process in practice according to the objectives of our research because we had explained all the principles and means of our research with the targets to the teachers in advance so as not to have misunderstandings later.

Based on the research objectives, we had online questionnaires on the platform of Telegram and Google Forms to obtain practical results, opinions, and answers of the subjects (students). As for the materials of the process, online sources, text, video, and audio materials had been chosen according to the study curriculum and requirements of higher education.

As for the variables of the research, we generally observed five variables, some of which happened to be as we had expected, and some of which did not for some reasons during the practice.

The first and foremost one is the dependent variable which is thought to be a central subject matter of the research and the other variables have an impact on it. The use of the platforms of SNSs and messengers in TE classes at higher education is considered to be dependent variable of the particular research.

An independent variable is a set of techniques that have been organized in order to see what influence it has on the dependent variable. 
Moderator variable - factors which could influence the suitability of the tasks and in general, materials chosen in accordance with the subjects' nationalities, ages and levels to reach the goals of the research progressively.

Control variables - the students' initial English knowledge on the target skills should be eliminated.

An intervening variable is a theoretical label that is indicated by the effectiveness of SNSs and messengers in the system of TE at higher education.

As for the methods of the research, we had selected the following methods to utilize during the whole investigation:

a) Observation method - while implementing the virtual platforms into practice we observed how the participants were using the platforms on the matter whether they could use the functions right or not and follow the instructions strictly or not because the most percentage of the productivity of our research depended on the participants' using the platforms right.

b) Statistical method - while collecting the responds of the students to the questionnaires we calculated them to reveal the productivity of the research methods based on which we could illustrate the practical results.

c) Experimental method - this method enabled us to practice the methods of our investigation on fostering the students' basic linguistic skills, such as reading, listening, reading, writing and practical grammar skills.

Furthermore, the methods of our research on fostering the students' basic linguistic skills were adjusted exclusively according to the functions of the virtual platforms of the blended learning approach and those methods will be illustrated with the practical results in the next part of the article 'Results and its discussion' in depth.

\section{RESULTS AND ITS DISCUSSION}

As this paragraph of the article is devoted to the analysis of the results on consolidating continuous education in the system of TE at higher education, the questionnaires for this part were about the sources presented on the platform of Telegram messenger. If we state the process of gaining the answers and opinions of the subjects on this part, we can mention that the questionnaires were presented to them at the end of our practice.

While obtaining the results of our investigation, we focused on the practical outcomes of implementing the innovative means into practice in order to highlight their benefits in increasing the quality and content factors of teaching English at higher education based on both reasonable theoretical and practical basis in the process of teaching and learning foreign languages. Furthermore, while analyzing the results of our research, we also paid our attention on the students' feedback on using these means in learning English distantly and innovatively. Accordingly, the analysis and results of our investigation will be presented by taking the above-mentioned factors into account step by step in the following.

\section{RESULTS OF THE QUESTIONNAIRE ON THE INNOVATIVE SOURCES}

As for the innovative sources of fostering basic five skills of the students, we utilized infographics on the platform of Telegram messenger where virtual groups and channels were created innovatively and on the platform of Instagram SNSs on which daily posts 
were released on fostering the five skills in a more visual form. So, according to the answers of the students, 13 students considered the infographics to be strongly effective, 4 students mentioned to be effective, and 1 student answered with 'no changes' with whom we discussed and figured out that this student had problems with the Internet while receiving the daily posts. As a result of these answers, it can be concluded that the source of infographics can be used on consolidating the content and quality of the system of TE at higher education (Table 1).

Tab. 1. Infographics on the platforms of Telegram and Instagram

\begin{tabular}{|c|c|c|c|c|}
\hline Choices & $\begin{array}{c}\text { Strongly } \\
\text { effective }\end{array}$ & Effective & Non effective & No changes \\
\hline $\begin{array}{c}\text { The number of the } \\
\text { choices }\end{array}$ & 13 & 4 & 0 & 1 \\
\hline
\end{tabular}

Furthermore, we utilized the function of Telegraph of the platform of Telegram messenger while providing the students with the text form of the sources online in order to consolidate continuous education at higher education with the help of blended learning. As for the answers of the students to this question, 15 participants approved of Telegraph function ('Instant view') by mentioning that this function was convenient enough to get acquainted with the new topics effectively while 3 students chose the choice of 'Almost effective' as they learnt new materials in the target language at university (Table 2). Hence, the function of Telegraph on providing students with the text versions of the materials in TFL can be applied into practice effectively.

Tab. 2. Telegraph version of the text forms of the topics on Telegram

\begin{tabular}{|c|c|c|c|c|}
\hline Choices & $\begin{array}{c}\text { Strongly } \\
\text { effective }\end{array}$ & $\begin{array}{c}\text { Almost } \\
\text { effective }\end{array}$ & Non effective & No changes \\
\hline $\begin{array}{c}\text { The number of the } \\
\text { choices }\end{array}$ & 15 & 3 & 0 & 0 \\
\hline
\end{tabular}

The next form of the source was audio versions of the topics on fostering practical grammar skills on the platform of Telegram messenger. As the most characteristic feature of blended learning, audio forms of the lessons recorded by the teacher had been planned to utilize according to the research plans, and the results happened to be as we had expected. As for this question, 15 participants answered positively with the answer of 'Strongly effective', and 3 students answered with 'Almost effective' with whom we discussed this condition and found out that they were much better at learning new topics by listening to them by a teacher lively at university (Table 3). However, we did not get negative responds to this question, and this could be summarized that audio lessons are also remarkably beneficial in continuous education.

Tab. 3. Audio versions of the lessons on the platform of Telegram

\begin{tabular}{|c|c|c|c|c|}
\hline Choices & $\begin{array}{c}\text { Strongly } \\
\text { effective }\end{array}$ & $\begin{array}{c}\text { Almost } \\
\text { effective }\end{array}$ & Non effective & No changes \\
\hline $\begin{array}{c}\text { The number of the } \\
\text { choices }\end{array}$ & 15 & 3 & 0 & 0 \\
\hline
\end{tabular}


Following this type of sources, we also utilized video versions of the lessons to consolidate continuous education taking the factors of quality and content on the platform of Telegram. As for the contents of the video lessons, they had been recorded focusing on the factors of time and level of difficultness of the topics on the five skills. Consequently, 16 students approved of this type of the sources while understanding new topics more effectively ('Strongly effective) whereas 2 students also answered positively with the answer of 'Almost effective' because they had some difficulties in downloading high quality videos on the platform of Telegram as a result of the Internet in their areas (Table 4). Taking the positive responds of the participants into account, it can be said that video versions of the lessons recorded by the teacher on the platform of Telegram could be effectively implemented into the system of TE at higher education.

Tab. 4. Video versions of the topics on the platform of Telegram

\begin{tabular}{|c|c|c|c|c|}
\hline Choices & $\begin{array}{c}\text { Strongly } \\
\text { effective }\end{array}$ & $\begin{array}{c}\text { Almost } \\
\text { effective }\end{array}$ & Non effective & No changes \\
\hline $\begin{array}{c}\text { The number of the } \\
\text { choices }\end{array}$ & 16 & 2 & 0 & 0 \\
\hline
\end{tabular}

While preparing the questions for Questionnaire №1, we also added the question on finding out the students' opinions on the innovative approaches and virtual learning environment on the platforms of SNSs and messengers. Before the students made their choices about those two factors of our research, we explained them to the students with the examples that we had utilized during the lessons because the participants of the research also needed to fully understand the objectives and tasks of our investigations on implementing the innovative methods and means, especially the platforms of SNSs and messenger independently and well. After that, we had a small discussion on this matter with the participants by asking them questions and answering to their questions individually. After having figured out that they understood, we allowed them to make their choices. Therefore, the next question of the questionnaire was about the innovative approaches of the teacher towards the lessons in the target language, and 18 participants $(100 \%)$ of the research approved of the innovative approaches of the research according to their choices (Table 5). Thus, it can be mentioned that the innovative approach of the research on implementing the platforms of SNSs and messengers into the system of TE at higher education can be approved of positively.

Tab. 5. Innovative approaches towards the system of TE at higher education

\begin{tabular}{|c|c|c|c|c|}
\hline Choices & $\begin{array}{c}\text { Strongly } \\
\text { approve }\end{array}$ & Approve & $\begin{array}{c}\text { Strongly } \\
\text { disapprove }\end{array}$ & Disapprove \\
\hline $\begin{array}{c}\text { The number of the } \\
\text { choices }\end{array}$ & 18 & 0 & 0 & 0 \\
\hline
\end{tabular}

After having received the answers to this questionnaire, we also distributed the next set of questions which was Questionnaire № 2. The first question of this questionnaire was about the platforms of SNSs and messengers which had been divided into two in order to form blended learning effectively and in the right system. It is also crucial for us to mention that we had selected the platforms of SNSs and messengers according to the objectives and tasks of 
our research at the beginning of the studies because we had analyzed the research literature materials and taken the condition of the technical provision of the students of the university into consideration to create convenient and innovative atmosphere of learning and teaching the basic skills of English during our research observations and practice. Thus, we included the platforms of Telegram messenger, Instagram and YouTube SNSs as the choices of the first question. As for the first question of the questionnaire was about the platforms to teach and learn the five skills innovatively, the results were 8 students for Telegram, 5 students for Instagram, and 5 students for YouTube (Table 6). Taking the results of this question into account, we can summarize that the platforms of SNSs and messengers could be implemented into the system of TE effectively in continuous education.

Tab. 6. Platforms of the SNS and messengers to conduct lessons

\begin{tabular}{|c|c|c|c|}
\hline Choices & Telegram & YouTube & Instagram \\
\hline The number of the choices & 8 & 5 & 5 \\
\hline
\end{tabular}

The next question was to identify the effectiveness of the platforms of the platforms of SNSs and messengers on testing the language learners' linguistic skills according to our research objectives. While testing students' linguistic skills, on the platforms of SNSs and messengers, we provided the participants with the information about the tests innovatively in order to instruct them how to do the tests and what elements of the tests to pay attention to get higher scores. Besides that, the process of testing the students was organized for all the subjects that we conducted during our practice. Three types of the questions were utilized on the platforms of SNSs and messengers, such as multiple choice, short question, checkbox question types online. As a result of this, we presented the platforms of Google Forms and Telegram messenger for the choices of this question. According to the answers of the students, 14 students (78 \% of all the participants) chose the platform of Google Forms, and 4 students (22\% of all the participants) selected the platform of Telegram messenger (Table 7). Analyzing the choices of the students, we figured out that the functions of testing students' linguistic skills on the platform of Telegram were not transparent enough in practice. Therefore, it can be concluded that the platform of Google Forms can be implemented into practice much more conveniently and effectively.

Tab. 7. Platforms to test the students' linguistic skills

\begin{tabular}{|c|c|c|}
\hline Choices & Telegram & Google Forms \\
\hline The number of the choices & $22 \%$ & $78 \%$ \\
\hline
\end{tabular}

\section{THE RESULTS ON THE SYSTEM OF ASSESSING THE STUDENTS ON THE VIRTUAL PLATFORMS}

The process of assessing language learners is a crucial part of TFL as this directly influences on a language learner's progress while learning a certain foreign language. This condition is the same in TE, and the system of TE at higher education plays a more significant role in preparing students as future personnel because while assessing students as language learners a teacher must pay attention a number of factors and follow modern innovative means of assessing them to make the process of teaching and learning English transparent enough in practice. As a consequence of such an approach of our research towards this part of the system, we tried to implement two platforms of the SNSs, which was Google Forms, and messenger, which was Telegram messenger into practice to achieve successful results at the 
end of our investigations. Besides that, we paid attention to not only the content but also the forms of the system of assessing the students following the tasks of our research. Thus, we implemented this method into the lessons of all the basic skills during our practice, and we obtained positive results at the end of this process. All of the participants (18 of them) approved of the methods of assessing them on the basic skills on the platforms of Google Forms and Telegram messenger via their responds according to the results of the questionnaire (Table 8).

Tab. 8. The Results of the Questionnaire for the Assessment Process

\begin{tabular}{|c|c|c|}
\hline Choices & Telegram & Google Forms \\
\hline $\begin{array}{c}\text { The number of the } \\
\text { choices }\end{array}$ & $50 \%$ & $50 \%$ \\
\hline
\end{tabular}

THE RESULTS ON PROVIDING THE STUDENTS WITH THE INNOVATIVE FEEDBACK. While a language learner is learning a particular foreign language, it is advisory for a teacher to provide him or her constructive and effective feedback to make the process convenient. Taking this factor into account, we had also decided to analyze this part of the system of TE at higher education by applying modern methods and means of TFL and ICT to update the process of providing students with innovative feedback. As we had mentioned the methods of our research for this part of our research, we implemented the innovative feedback into the basic lessons of English during our practice and obtained their results through the questionnaire at the end of the process. As for the feedback on developing the speaking skills, 17 students supported our method - providing with innovative feedback; 16 students made their choices positively for the feedback of the reading skills; 18 students approved of the feedback method for the writing skills; 15 students made their positive choices for the feedback of improving the listening skills, and 18 of them chose the innovative feedback on improving the practical gramma skills as one of the most effective ones according to their responds to the questionnaire (Table 9).

Tab. 9. The Results of the Questionnaire for the Innovative Feedback

\begin{tabular}{|c|c|c|c|c|c|}
\hline Choices & Speaking & Reading & Writing & Listening & Grammar \\
\hline $\begin{array}{c}\text { The number } \\
\text { of the } \\
\text { choices }\end{array}$ & 17 & 16 & 18 & 15 & 18 \\
\hline
\end{tabular}

Having analyzed the responds of the students to the questionnaire, we addressed to the second group of the participants - teachers to discuss the final results of our practical methods for the methodological aspects of implementing the platforms of the SNSs and messengers. As for the methods of improving listening skills on the platforms of SNSs and messenger, the teachers supported the variety of the tasks which were released on the platforms daily. Besides that, the group of the teachers expressed their positive reflections about the posts on the platform of Instagram SNS as those posts assisted the students to learn the key strategies of doing the listening tasks more successfully and easily. Having analyzed those methods, we discussed the methods of our research to improve the students' reading skills. While analyzing the methods for the reading skills, the teachers focused on the functions of the platforms of 
Google Forms, Telegram messenger, and Instagram SNS on testing the language learners' linguistic skills in innovative forms conveniently. Moreover, they mostly approved of the materials on providing the students with the instructions in visual forms innovatively. Following those methods, the methods of fostering writing skills were also supported by the teachers since the whole process had been organized by following the right principles and strategies on improving the students' academic and non-academic writing skills, for example, while learning how to write letters and argumentative essays in practice. The methods of fostering speaking skills were also analyzed by the teacher deeply, and they supported the functions and materials which had been presented on the platforms of the SNSs and messenger as they helped the students to improve their speaking skills more effectively and innovatively according to the analysis of the questionnaire. Like the abovementioned methods of fostering the basic four skills, the methods of improving the practical grammar skills of the students were given primary focus by the group of the teachers remarkably, and they strongly approved of the process of testing the students' knowledge on the platforms of Google Forms and Telegram messenger.

Finally, we presented the results of the questionnaire to the teachers on the process of assessing and providing the students with feedback innovatively. While the teachers were analyzing the results of the methods of assessing, we explained the tasks and objectives of our research for this part by mentioning the form and means of the assessment system. As a result of this, the teachers made their positive choices for the forms of the assessment on the platform of Telegram messenger and the functions of assessing the students on the platform of Google Forms. After that, we distributed our methods of providing the students with the innovative feedback to the teachers to analyze with the responds of the students having studied all of them, all of the teachers supported the innovative feedback as this approach helped the students to work on themselves more practically and automatically in practice. Thus, our discussion with the group of the teachers was effective in general and they stated one point that they would use our methods at their lessons following the instructions and principles of our investigations.

\section{CONCLUSIONS.}

Taking all the theoretical and practical analyses of the research into consideration, we can conclude that the practical results of our methods which were implemented into practice to resolve the problems have been illustrated in detail. As for the factors of content and quality of the continuous education, we gained the results of our methods trough the answers of the students to the questionnaires and the results of our discussions with the teachers. Therefore, we analyzed the study materials, such as video, text, infographic, and audio versions of the topics according to the choices of the students the questions of the questionnaire on this matter by outlining them via tables in order to highlight the productivity and effectiveness of the sources in practice. Following that, we collected the results of the choices of the students about the platforms of the SNSs and messenger that we implemented into practice along with the positive outcomes, thereby discussing them with the teachers and considering the applied methods to be effective based on those successful achievements. Besides that, we have illustrated the results of our methods that we implemented into the system of TE at higher education to assess and provide the students with the innovative feedback on the platforms of the SNSs and messenger by highlighting their functions during our research. Therefore, as we presented the successful 
results of the methods along with the positive reflections of the teachers in the analyses, we can conclude that all the methods of our research to resolve the problems of continuous education and methodological matters of the system of TE at higher education can be applied into practice fully by resolving some minor technical mistakes correctly. Therefore, we, teachers of foreign languages, must be fully ready for the tasks and requirements of the current rapidly changing world as Shavkat Mirziyoyev mentioned in his address to teachers on September 30, 2020: "Today, first of all, I want to appeal to educators, to all compatriots: dear friends, if we sincerely strive, act in harmony and decisively, we will be able to achieve the highest of ends. We are a people with an ancient history and rich culture, with great spiritual potential. We have the longing for science in our blood, it is in our genes" [1].

\section{REFERENCES}

1. President Shavkat Mirziyoyev's speech at the Independence Day festive occasion devoted to the 29th anniversary - Newspaper “Xalq so'zi” № 186 (7688), 01.09.2020.

2. Alexander, S. 2010. Flexible Learning in Higher Education. In Penelope Peterson; Eva Baker; Barry McGaws (eds.). International Encyclopedia of Education (Third ed.). Oxford: Elsevier. pp. 441-447. doi:10.1016/B978-0-08-044894-7.00868-X. ISBN 9780080448947.

3. Alexander, S. \& McKenzie, J. 1998. An Evaluation of Information Technology Projects for University Learning. Canberra, Australia: Committee for University Teaching and Staff Development and the Department of Employment, Education, Training and Youth Affairs.

4. Bersin, J. 2004. How Did We Get Here? The History of Blended Learning. The Blended Learning Book: Best Practices, Proven Methodologies, and Lessons Learned. Wiley. ISBN 9780-7879-7296-7.

5. Bonk, C.J. \& Graham, C.R. 2004. The handbook of blended learning environments: Global perspectives, local designs. San Francisco: Jossey-Bass/Pfeiffer. p. 5.

6. Friesen, N. 2012. Report: Defining Blended Learning.

7. Garrison, D. R.; Kanuka, H. 2004. Blended learning: Uncovering its transformative potential in higher education. The Internet and Higher Education. 7 (2): 95-105. doi:10.1016/j.iheduc. 2004.02.001.

8. Kim A. Rotational models work for any classroom. Education Elements. Retrieved 2014-06-05.

9. Saritepeci, M; et al. 2015. The effect of blended learning environments on student motivation and student engagement: A study on social studies course. Education and Science.

10. 6 Models of Blended Learning. DreamBox. Retrieved 2014-11-25.

11. Blended Learning 101. Aspire Public Schools. Archived from the original (PDF) on 2014-10-21. Retrieved 2014-11-25.

12. BLENDED LEARNING Defining Models and Examining Conditions to Support Implementation. Philadelphia Education Research Consortium (PERC). September 2014. Retrieved May 10, 2016.

13. The Four Important Models of Blended Learning Teachers Should Know About. Educational Technology and Mobile Learning. Retrieved 2014-11-25.

14. Top 5 Benefits of a Blended Learning Platform. Retrieved 2015-07-04.

15. https://en.wikipedia.org/wiki/Blended_learning 